\title{
Minute Times Millimole per Liter per Kilogram per Meter Squared
}

National Cancer Institute

\section{Source}

National Cancer Institute. Minute Times Millimole per Liter per Kilogram per Meter

Squared. NCI Thesaurus. Code C111264.

Minutes times millimoles per liter, divided by kilograms per meter squared. 